\title{
Wave hydrodynamics around a multi-functional artificial reef at Leirosa
}

\author{
Ana Mendonça • Conceição Juana Fortes • \\ Rui Capitão • Maria da Graça Neves • Theo Moura • \\ José Simão Antunes do Carmo
}

Received: 21 April 2010 / Revised: 15 November 2010 / Accepted: 24 November 2010

(C) Springer Science+Business Media B.V. 2012

\begin{abstract}
This paper describes an application of the Boussinesq-type COULWAVE model to study the wave hydrodynamics in the vicinity of a multi-functional artificial reef (MFAR). This reef is under investigation and consists of a supplementary protection solution for the Leirosa sand dune system located at South of Figueira da Foz, on the Portuguese West coast. Such installation near the coastline is expected to contribute to enhance the surfing conditions in the area, protect the sand dune system in the surroundings of Leirosa beach, and increase its environmental value. Numerical calculations with the COULWAVE model were performed for four test cases, considering two reef geometries (differing in the reef angle) and two incident wave conditions (storm condition and a common wave condition). Comparisons between the results obtained, in terms of wave
\end{abstract}

\footnotetext{
A. Mendonça $(\varangle) \cdot$ C. J. Fortes · R. Capitão · M. G. Neves •

T. Moura

Laboratório Nacional de Engenharia Civil,

Departamento de Hidráulica e Ambiente,

Lisbon, Portugal

e-mail: amendonca@lnec.pt

C. J. Fortes

e-mail: jfortes@lnec.pt

R. Capitão

e-mail: rcapitao@lnec.pt

M. G. Neves

e-mail: gneves@lnec.pt

T. Moura

e-mail: tmoura@lnec.pt

J. S. Antunes do Carmo

Departamento de Engenharia Civil, IMAR/FCTUC,

3030-788 Coimbra, Portugal

e-mail: jsacarmo@dec.uc.pt
}

heights and breaking line positions allow us to assess the influence of the reef on the hydrodynamics near the beach and around the reef. Moreover, the reef performance was analysed in terms of surfability and coastal protection. The surfability parameters (breaker height, Iribarren number and peel angle) were calculated for each test case using the numerical wave heights, wave directions and wave breaking positions. Comparisons of parameters allow characterizing the most appropriate configuration of the reef to improve the surfing conditions in the study area. A methodology based on numerical free surface elevations and horizontal velocity components was developed to calculate wave directions, since this is not a direct output of the COULWAVE model. Concerning coastal protection, analyses of the mean currents around the reef were used together with observations of the velocity cells near the shoreline as an indication of the sediment transport.

Keywords Artificial reefs · Numerical modelling · COULWAVE model · Wave breaking · Surfability parameters $\cdot$ Currents

\section{Introduction}

The Leirosa sand dune system is located to the south of Figueira da Foz, midway along the West Atlantic coast of Portugal $\left(40^{\circ} 03^{\prime} \mathrm{N}, 08^{\circ} 53^{\prime} \mathrm{W}\right)$. This coastal stretch is characterized by strong erosion, mainly due to littoral drift retention caused by the Figueira da Foz port and the reduced sediment deposition which is a consequence of the interventions carried out in the Mondego River (Duarte and Reis 1992). This led to the construction of groynes along this coastal area to protect several urban populations, including Leirosa (Dias et al. 1994). 
Close to the Leirosa costal dunes are two cellulose pulp and paper companies, Celbi and Soporcel. In 1995 a submarine pipeline was built to discharge their industrial effluents. After the installation of this pipeline the dune was rebuilt about $1 \mathrm{~km}$ south of the Leirosa groyne, using sand and rocks as inner core for protection. In the following years the dune system suffered the effects of considerable erosion, which was felt all along the coastline south of Figueira da Foz (Antunes Do Carmo et al. 2010). The Leirosa sand dune system has been the scene of three major dune rehabilitation interventions in the past nine years (Fig. 1a). The first involved the reconstruction of the sand dunes followed by re-vegetation. The second intervention consisted of installing geotextile containers filled with sand, and the last one was based on the use of geotextile tubes filled with a suspension of locally available sand and water (Fig. 1b).

In order to guarantee the favorable evolution of the dune system by anticipating and preventing any problems that might occur, a monitoring program has been implemented since early 2001. Both the average sand mobility and the characterization of the vegetation in the Leirosa dunes started immediately after the first replanting work. The sand mobility has been measured by graduated wooden poles placed in different areas of the Leirosa dunes, and the identification of new plants that colonized the Leirosa dunes continued periodically in subsequent years.

As shown in Antunes Do Carmo et al. (2010), the stretch of dunes under intervention remained stable for the years 2006 to 2010, whereas both the sides of this stretch suffered strong erosion for hundreds of meters (about $4 \mathrm{~m}$ to $5 \mathrm{~m}$ per year), particularly since 2000 .

Lately, a multi-functional artificial reef (MFAR) has been studied to analyze its contribution to the enhancement of the surfing conditions and the protection of the sand dune system. A MFAR is an innovative way of protecting the coastline involving submerged breakwaters which, besides helping to protect the local coastline, may contribute to the improvement of the surfing conditions. Moreover, this solution will increase the environmental value of the local area, and will provide an excellent substrate for marine flora and the development of a diverse ecosystem (Jackson et al. 2004), with the appreciable touristic and economic benefits. Some limitations of MFAR structures include the lower experience by coastal engineering contractors in the use of sand-filled geotextile systems, the lower resistance of the geotextil material to mechanical damage and vandalism, and the lack of design guidance of coastal structures using geotextiles.

The study of the MFAR functionality at Leirosa involved:

1. Definition of the design wave parameter for which the artificial reef will be efficient, based on the local wave regime;

2. Definition of the reef solution (dimensions, geometry and location);

3. Analysis of the MFAR functionality based on the numerical simulations using the COULWAVE model (Lynett and Liu 2002), for each reef solution, which includes:

a) Determination and analysis of the surfing conditions;

b) Determination and analysis of the mean current field as an indication of the MFAR functionality for coastal protection.

This paper presents the numerical study developed to analyze the functionality of a MFAR planned to be constructed at Leirosa. The incident wave conditions were defined based on the local wave regime at Leirosa beach, as established in Mendonça et al. (2009) and on the study of Ten Voorde et al. (2008). The reef's geometry and location were based on the theoretical study developed in Ten Voorde et al. (2008). Two different geometry reefs were tested, being the main differences between them related with the angle of the reef.

The propagation of the incident wave conditions was made with the Boussinesq-type model, COULWAVE. Numerical tests were performed with two different reef geometries and two incident wave conditions, in order to evaluate the reef's influence on the hydrodynamics around the reef and near the beach.

Moreover, based on the COULWAVE numerical results (wave height, period, direction and wave breaking position) the functionality of the reef for surfing was characterized by three surfing parameters: Iribarren number, peel angle and
Fig. 1 a Leirosa sand dune system, b Protection barrier using geotextiles applications
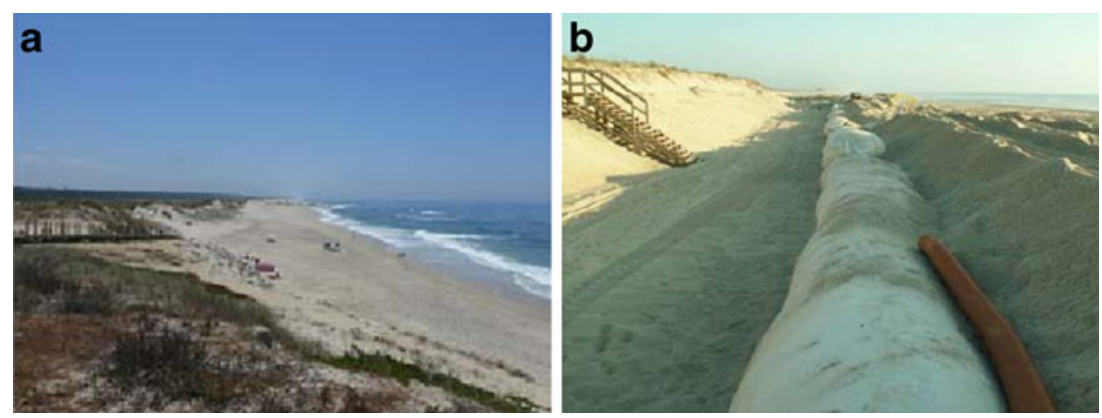
wave height at breaking. The calculation of the wave directions in the domain (which is not a direct result of COULWAVE model) was made through Longuet-Higgins et al. (1963) method. Finally, a first indication about the sediment transport was given by the mean current field.

\section{Functionality of a multi-functional artificial reef}

The efficiency of a MFAR is related to its functionality regarding the two main goals: surfability and coastal protection.

\section{Surfability parameters}

The creation of surfing conditions is an important intent of a MFAR. The key surfing parameters used in the design of a MFAR is the breaker type, the peel angle, the wave height at breaking and the currents.

\section{Breaker type}

The shape of a breaking wave is of great importance for surfing. Battjes (1974) used the surf-similarity parameter, $\xi_{b}$ (Eq. 1), to describe the breaker type on single slopes:

$\xi_{b}=\frac{s}{\sqrt{H_{b} / L_{0}}}$

where $\xi_{b}$ is the inshore Iribarren number, $\mathbf{s}$ is the bottom slope, $H_{b}$ is the wave height at breaking and $L_{0}$ is the deep water wave length. The values of the Iribarren number that correspond with each breaker type are presented in Table 1.

Peel angle

The peel angle, related to the break angle and the wave obliquity at the broken depth, determines the speed that the surfer must generate to stay ahead of the breaking section of the wave.

The peel angle $(\alpha)$ is the angle enclosed by the wave crest and the breaker line (Walker 1974), or the angle enclosed by the velocity vectors of the peel rate $\vec{V}_{p}$ and the down-line velocity $\vec{V}_{S}$ (Henriquez 2004), (Fig. 2).

$\vec{V}_{s}=\frac{\vec{c}}{\sin \alpha}$

where $c$ is the wave celerity.

Table 1 Breaker type transition values for inshore Iribarren number

\begin{tabular}{ll}
\hline Breaker type & Range \\
\hline Surging/collapsing & $\xi_{b}>2.0$ \\
Plunging & $0.4>\xi_{b}>2.0$ \\
Spilling & $\xi_{b}<0.4$ \\
\hline
\end{tabular}

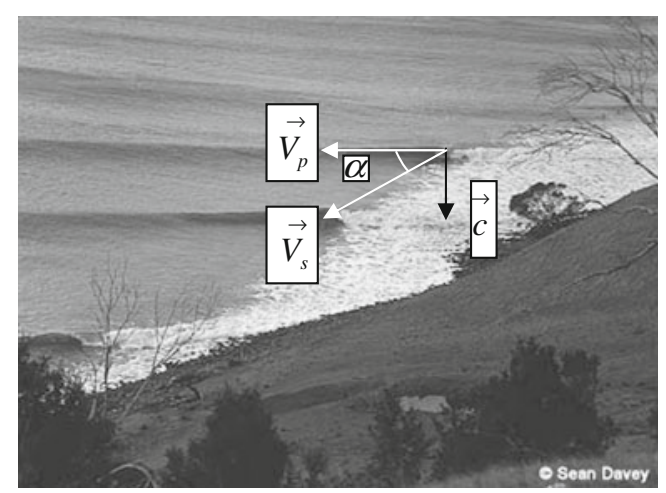

Fig. 2 Illustration of wave celerity vector $\vec{c}$, peel rate $\vec{V}_{p}$, down line velocity $\vec{V}_{s}$ and peel angle $\alpha$ (Source: surfermag.com)

Peel angles vary between $0^{\circ}-90^{\circ}$, with zero peel angles corresponding to what is referred as a 'close out' where the waves break simultaneously along the entire crest. As peel angles increase the speed of breaking along the crest, which approximates the surfer velocity, decreases to a speed suitable for experienced surfers. This occurs for peel angles around $30^{\circ}-45^{\circ}$ with the optimal peel angle for most recreational surfers considered to be in the range $45^{\circ}-65^{\circ}$.

Wave height

Surfers that surf on a long board are still surfing when waves are $0.15 \mathrm{~m}$ high, whereas those that are towed into waves ride the biggest waves they can find, up to $20 \mathrm{~m}$. On the whole, waves between $0.5 \mathrm{~m}$ and $10 \mathrm{~m}$ are considered surfable (Henriquez 2004). However, in order to study the viability of a MFAR, wave heights between $1 \mathrm{~m}$ and $3 \mathrm{~m}$ are the most common values, and are adjusted according to the target level of surfers for which the MFAR is being designed.

\section{Currents}

Currents around a surf break are of vital importance when considering the surfability of the break. There could be waves in perfect surfing condition but yet unreachable due to strong currents. Usually these cases are rare but it is not ideal to have to be constantly paddling to keep positioning.

Rip currents can destroy good surfable waves. Rip currents are narrow strong currents that move seaward through the surf zone (Bowen 1969). When the rip-current flows through the breaker zone the wave seems to get a rough surface and breaks in a hesitating manner making the waves unsuitable for surfing. Rip-currents can also be advantageous; the surfer can use the rip-current to get outside the breaker zone more easily (Henriquez 2004). 
Coastal protection

One of the main goals of a MFAR is to prevent coastal erosion and increase, in combination or not with sand nourishment, the stability of beaches. These sorts of coastal protection are possible due to the reduction of the wave loads on the coast by the MFAR through a series of wave transformation processes occurring on the structure, i.e., reflection and energy dissipation due to waves breaking on the structure and to flow circulation inside the porous media.

Knowledge of the shoreline response on a reef is an important factor for coastal protection purposes. For that a morphodynamic study should be done. However, in terms of hydrodynamics, the mean current field could give a first indication about the sediment transport.

\section{Numerical modeling}

In order to analyse the hydrodynamics around a reef, the methodology of Neves et al. (2007) is adopted, which involves the following steps:

1. Establishment of the local wave regime;

2. Based upon (1), definition of the design wave parameters for which the artificial reef will be functioning;

3. Analysis of the hydrodynamics around the reef:

a. Definition of the study area (domain and bathymetry);

b. Definition of the geometry, orientation and location of the reef based upon Ten Voorde et al. (2008) reef study;

c. Propagation of the design wave parameters, using the numerical model COULWAVE, (Lynett and Liu 2002), for each reef solution;

Two reef geometries were studied by varying the slope of the artificial reef. The comparison of the numerical results (surfability parameters and currents) for these two different artificial reef geometries permits to evaluate which is the more adequate.

The numerical model

COULWAVE (Lynett and Liu 2002) is a nonlinear wave propagation model based upon a multi layer approach for the integration of the primitive equations of motion (continuity and momentum equations). This approach leads to a set of model equations without the high-order spatial derivatives associated with high-order polynomial approximations.

The optimized model equations show good linear wave characteristics up to a $k h$ of 8 , while the second-order nonlinear behavior is well-captured to $k h \sim 6$, being $k$ the wave number and $h$ the water depth. This is a greater than twofold extension to higher $k h$ over existing $\mathrm{O}(1)$ Boussinesqtype. To enable the Boussinesq model to simulate surf zone hydrodynamics, energy dissipation due to wave breaking is treated by introducing an eddy viscosity term into the momentum equations, with the viscosity strongly localized on the front face of the breaking waves. Wave run-up on the beach is simulated using a permeable seabed technique. Both wave breaking and run-up schemes follow the work of Kennedy et al. (2000).

Even though it has to be mentioned that, unlike 3D or quasi-3D Navier Stokes-type models, the overturning of the crest of the wave during breaking can never occur in a Boussinesq model.

In the next sections the study area, the local wave conditions and the main conditions for the application of the COULWAVE model are presented.

Local wave regime and design wave parameters

For the characterization of the local wave regime at Leirosa, the methodology of Fortes et al. (2007) described in Mendonça et al. (2010) was followed. Based on the local wave regime and the design waves considered in the study of Ten Voorde et al. (2008), and taking into account that the reef will be designed with two goals, namely costal protection and the increase of surfing possibilities, two wave conditions (wave height, $\mathrm{H}$ and wave period, $\mathrm{T}$ ) were simulated in this paper for two reef geometries differing in the reef angle $\left(44^{\circ}\right.$ and $\left.65^{\circ}\right)$ :

- The design condition for coastal protection (storm condition): $\mathrm{H}=4 \mathrm{~m}, \mathrm{~T}=15 \mathrm{~s}$;

- The design condition for surfing (common condition): $\mathrm{H}=1.5 \mathrm{~m}, \mathrm{~T}=9 \mathrm{~s}$.

The incident angle of the waves is chosen to be zero degrees, since the point of the crest will be directed toward on of the most common wave directions, giving the best surfing conditions as derived by Ten Voorde et al. (2008). A medium tide level of $2.0 \mathrm{~m}$ (CD) was considered in these calculations since it was considered the more interesting to be presented based on previous results for different tidal conditions (Mendonça et al. 2010).

Reef geometry

The local bathymetry of the Leirosa's coastal area was obtained based on data coming from:

- Hydrographic Institute. Hydrographic Chart no. 24202. "Aveiro a Peniche". Scale 1:150 000. 1st Edition, October, 2000;

- CELBI/SOPORCEL, Topo-hydrographic Chart no. C135C0005, "Levantamentos topo-hidrográficos do emissário CELBI/SOPORCEL”. Scale: 1:2000, June, 2002;

- Instituto Hidrográfico. Hydrographic Chart no. 3. "Cabo Mondego ao Cabo Carvoeiro". Scale: 1:150 000, 6th Edition, May 1970. 
The obtained scatter set is presented in Fig. 3-The reef geometry defined by Ten Voorde et al. (2008) was implemented in the area of study. Two different reef angles, $45^{\circ}$ and $66^{\circ}$, were tested (Fig. 3c and d).

Wave model conditions

The computational domain is around $1870 \mathrm{~m}$ in the longshore and $1670 \mathrm{~m}$ in the cros-shore direction with a constant node spacing of around $d x=d y=2.0 \mathrm{~m}$ and a Courant number of 0.5. The total simulation time was $800 \mathrm{~s}$. A flat bottom is placed in front of the slope where waves are generated using the source function method (Wei et al. 1999). The source function is located at $x=80 \mathrm{~m}$ along the y direction (Fig. 4).

Two sponge layers are used, one in front of the offshore boundary to absorb the outgoing wave energy, and the other on the beach, both with a width of 0.5 times the wavelength of the incident wave wavelength.

The characteristics of the simulations for the different cases are described in Table 2.

The numerical results obtained by the model are the time series of the free surface elevation, the two velocity components, $u$ and $v$, and the breaking areas.
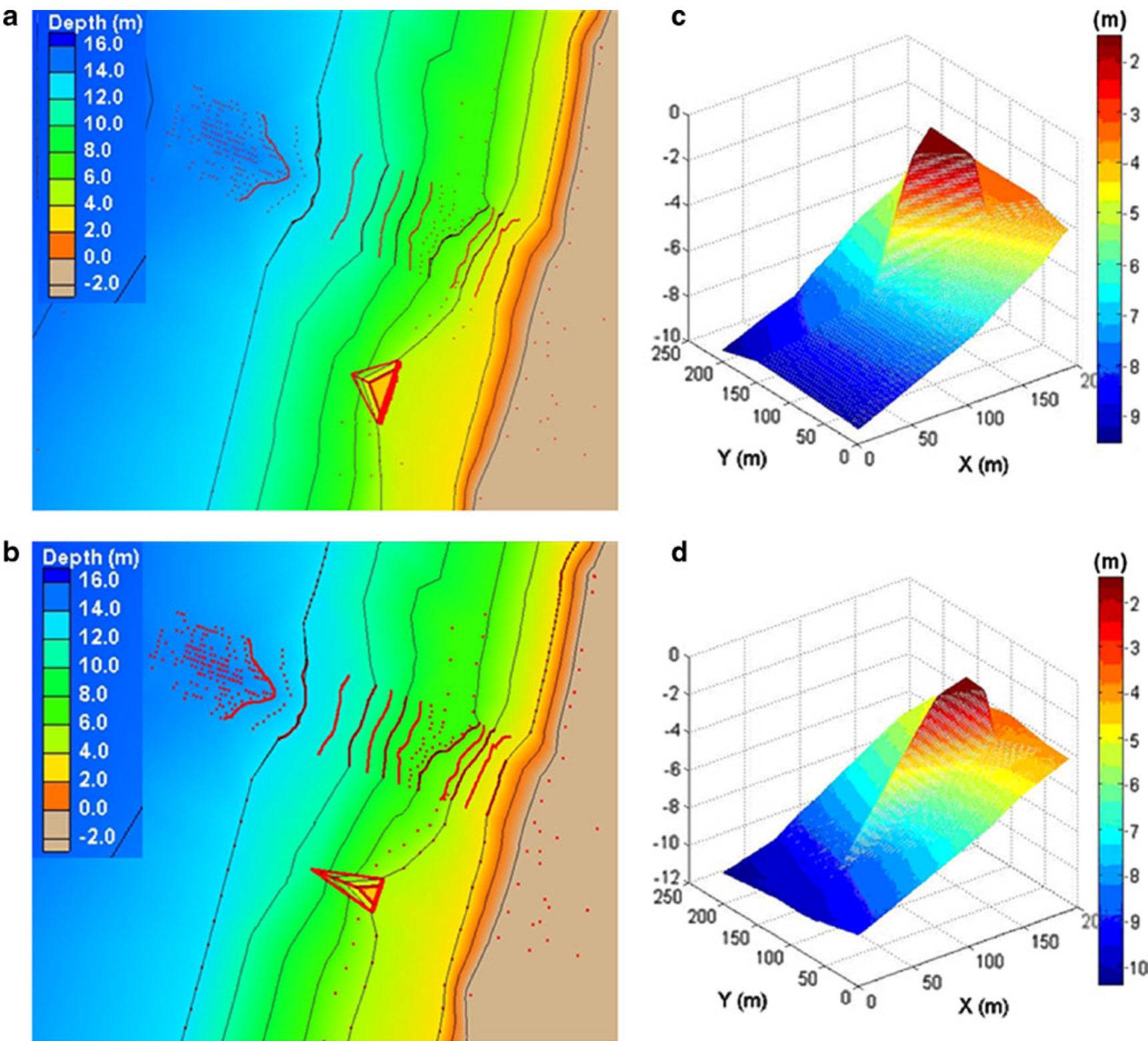

Fig. 3 Bathymetric data and location of the artificial reef: a Reef geometry with a $45^{\circ}$ angle; b Reef geometry with a $66^{\circ}$ angle, $\mathbf{c}$ Reef geometry detail with a $45^{\circ}$ angle, $\mathbf{d}$ Reef geometry detail with a $66^{\circ}$ angle 


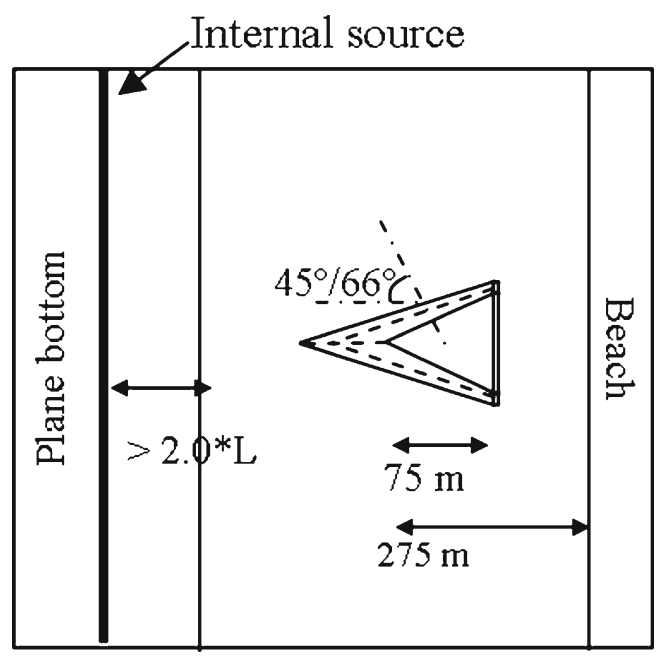

Fig. 4 Schematic representation of the simulated geometry (not at scale)

Notice that some preliminary tests were performed in order to define the empirical parameters related with bottom friction and breaking scheme, Mendonça et al. (2009).

\section{Results: analysis of the reef performance}

The numerical simulations to study the $2 \mathrm{DH}$ behaviour of the hydrodynamics around the MFAR have been done for four cases: two reef geometries, varying in the reef angle $\left(45^{\circ}\right.$ and $\left.66^{\circ}\right)$, for the two already mentioned wave conditions.

Surfability—wave height, breaking line, Iribarren number and peel angle

The surfability parameters described in section 2.1, namely the breaker height, the Iribarren number and the peel angle, are analyzed. The results of the simulations with COULWAVE give the possibility to study the position of the breaker line and the wave height around the reef.

For each wave condition defined in section 3.2 and for the two geometries of the reef previously defined, the numerical model COULWAVE was applied. For each condition (see Table 2) the results of the wave heights and the breaking line are presented in Fig. 5, the wave height along the breaking line is presented in Fig. 6 and the Iribarren number in Fig. 7.

From Fig. 5, it is clear that the presence of the reef alters significantly the wave heights due to refraction and diffraction effects. There is an increase of the wave height along the reef as a consequence of the decrease of the depth.

For the cases representative of storm condition, $\mathrm{C} 1$ and $\mathrm{C} 2$, the wave is breaking near the apex of the structure, parallel to the coast, with wave heights of around $4.5 \mathrm{~m}$. For the cases representative of common condition, $\mathrm{C} 3$ and $\mathrm{C} 4$, the artificial reef induces an increase of the wave height especially in the apex of the structure and a breaking line that follows its geometry.

The development of the breaker wave height along the breaker line is presented in Fig. 6, where the blue and the red rectangles represent the apex of the structure. The higher the skill of the surfer, the higher the wave is preferred. A tendency is observed for all the cases of an increasing of the wave height starting at the apex of the reef through around the middle of the breaker line. Concerning the geometry that gives higher wave height values, the tendency is not clear and more tests should be done.

The development of the Iribarren number along the breaker line is given in Fig. 7, where the green rectangle represents the apex of the structure.

For the simulated cases, the Iribarren number varies between 0.7 and 1.1, corresponding to a plunging breaking. A common tendency is observed: from the apex of the structure and in the direction of the shoreline, following the breaker line, the Iribarren number increases. In order to catch the wave in the beginning, a smaller wave value of about 0.6 at the beginning of the ride is preferred. Figure 7 shows values at the apex, corresponding to the beginning of the ride, from 0.70 to 0.86 .

The peel angle along the breaker line, related to the velocity that a surfer can reach and its skill, is expected to start at around $27^{\circ}$ for professional surfers, reaching around $60^{\circ}$ for standard surfers. For that, it is necessary to know the wave direction along the breaker line.

COULWAVE outputs include the free surface elevation in time and in space and the horizontal velocity components,

Table 2 Main characteristics of model simulation

\begin{tabular}{llllllc}
\hline & Reef angle $\left(^{\circ}\right)$ & $\mathrm{H}(\mathrm{m})$ & $\mathrm{T}(\mathrm{s})$ & $\begin{array}{l}\text { Number of grid points } \\
\text { per wavelength }\end{array}$ & Grid size (m) & Time step (s) \\
\hline $\mathrm{C} 1$ & 45 & 1.5 & 9 & 43 & 2.14 & 0.09288 \\
$\mathrm{C} 2$ & 45 & 4.0 & 15 & 60 & 2.77 & 0.11999 \\
$\mathrm{C} 3$ & 66 & 1.5 & 9 & 43 & 2.14 & 0.09288 \\
$\mathrm{C} 4$ & 66 & 4.0 & 15 & 70 & 2.37 & 0.10285 \\
\hline
\end{tabular}




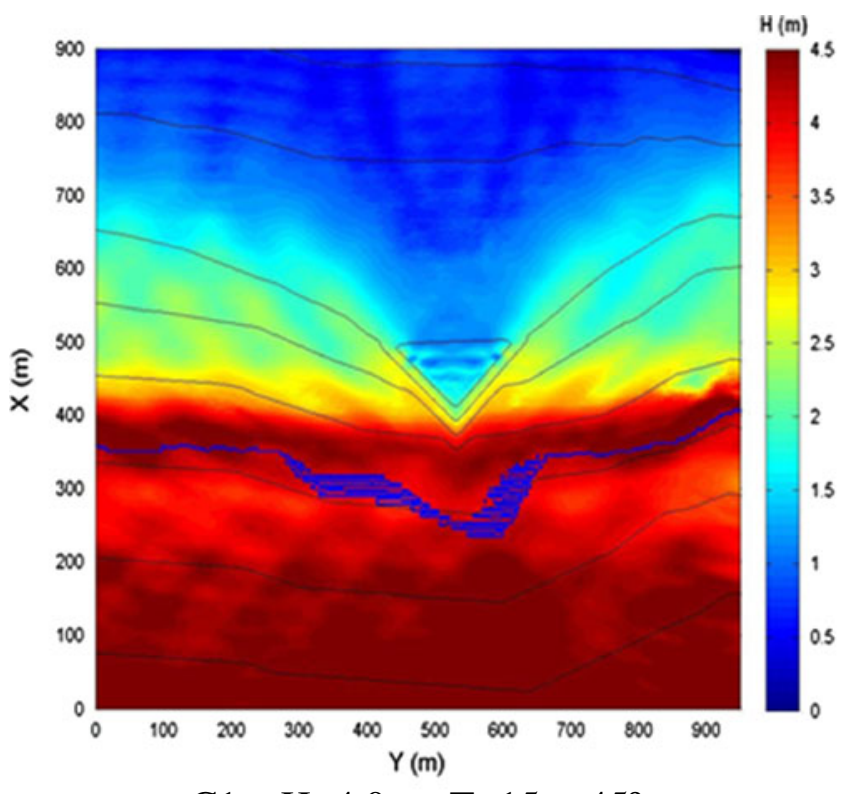

$$
\mathrm{C} 1-\mathrm{H}=4.0 \mathrm{~m}, \mathrm{~T}=15 \mathrm{~s}, 45^{\circ}
$$
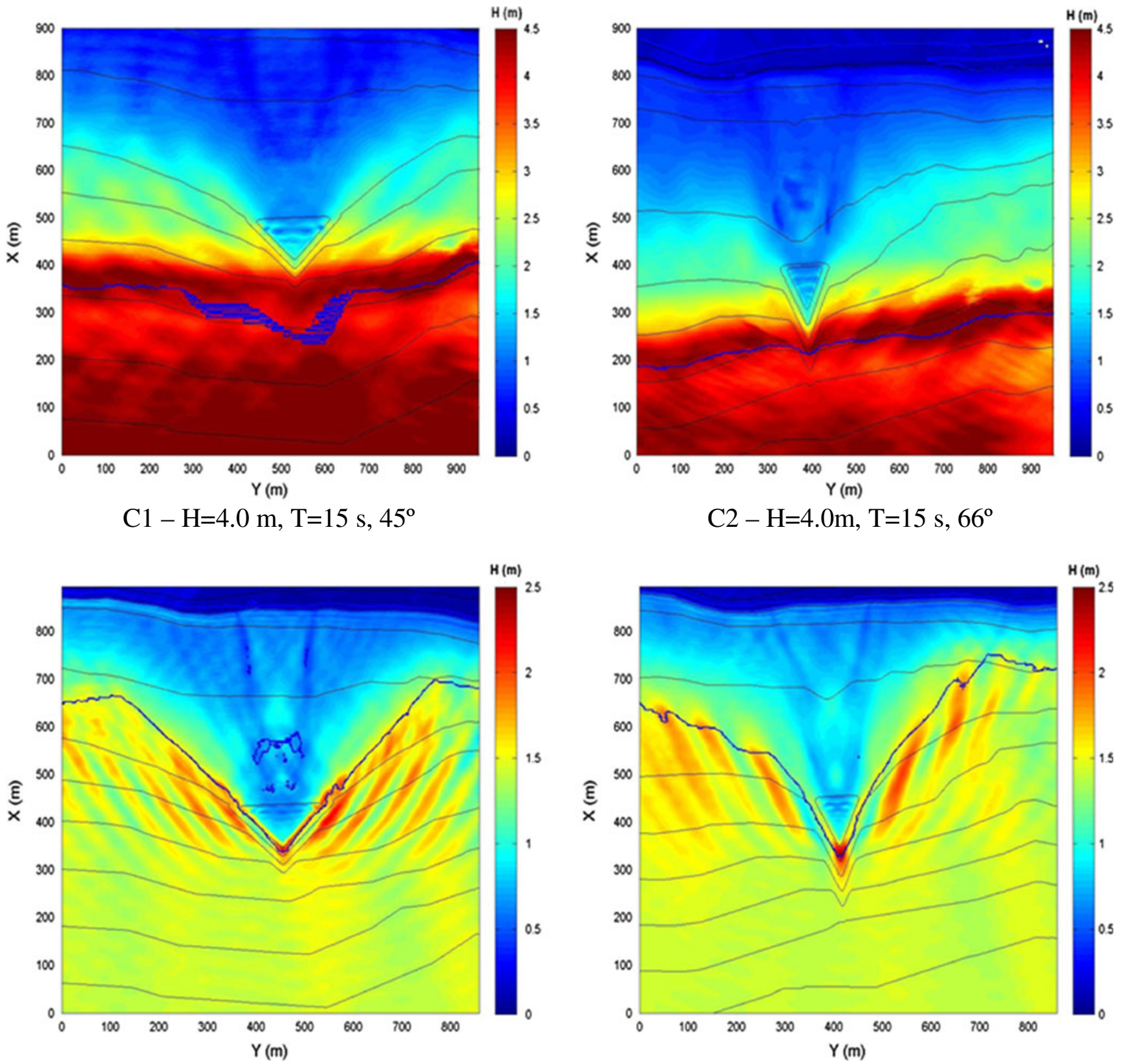

$$
\mathrm{C} 3-\mathrm{H}=1.5 \mathrm{~m}, \mathrm{~T}=9 \mathrm{~s}, 45^{\circ}
$$

$\mathrm{C} 4-\mathrm{H}=1.5 \mathrm{~m}, \mathrm{~T}=9 \mathrm{~s}, 66^{\circ}$

Fig. 5 Wave heights and wave breaking lines around the reef area

$u$ and $v$, that represent the local flow direction. However, the wave direction is not a direct output.

To calculate the mean wave direction, $\theta(f)$ and the directional spread $s(f)$, in this study the methodology of Longuet-Higgins et al. (1963) is followed, by considering arrays of the free surface elevation and the velocity components time series and performing a directional spectra analysis, similar to what might be done in a laboratory flume to determine wave direction from a set of wave gages.
Longuet-Higgins et al. (1963) has described the application of a general Fourier series expansion of the spreading function $D(\theta)$. Expanding $D(\theta)$ in a Fourier series gives:

$D(\theta)=\frac{1}{\Pi}\left\{\frac{1}{2}+\sum_{n=1}^{2}\left[a_{n} \cos (n \theta)+b_{n} \operatorname{sen}(n \theta)\right]\right\}$

Working with free surface elevation-velocity measurements $(\eta, u, v)$, estimates of the first four Fourier coefficients 

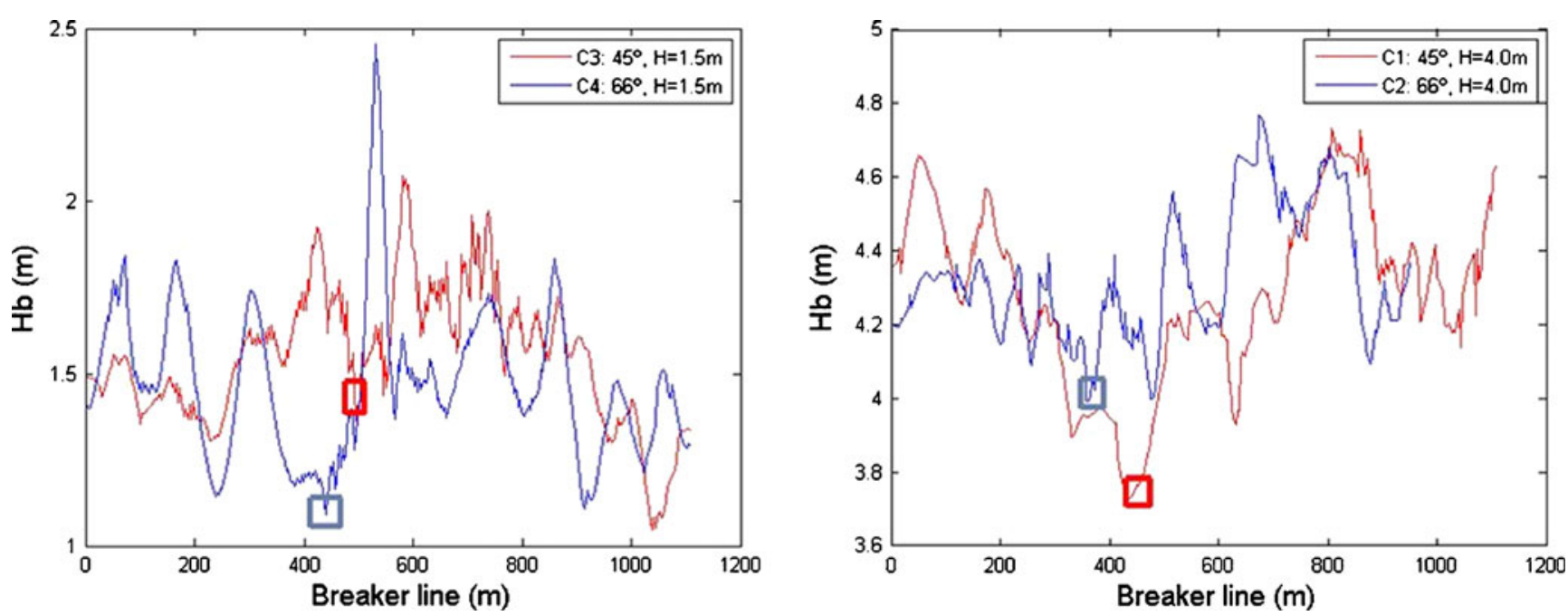

Fig. 6 Wave height along the breaker line. Blue and red squares represent the apex of the structure
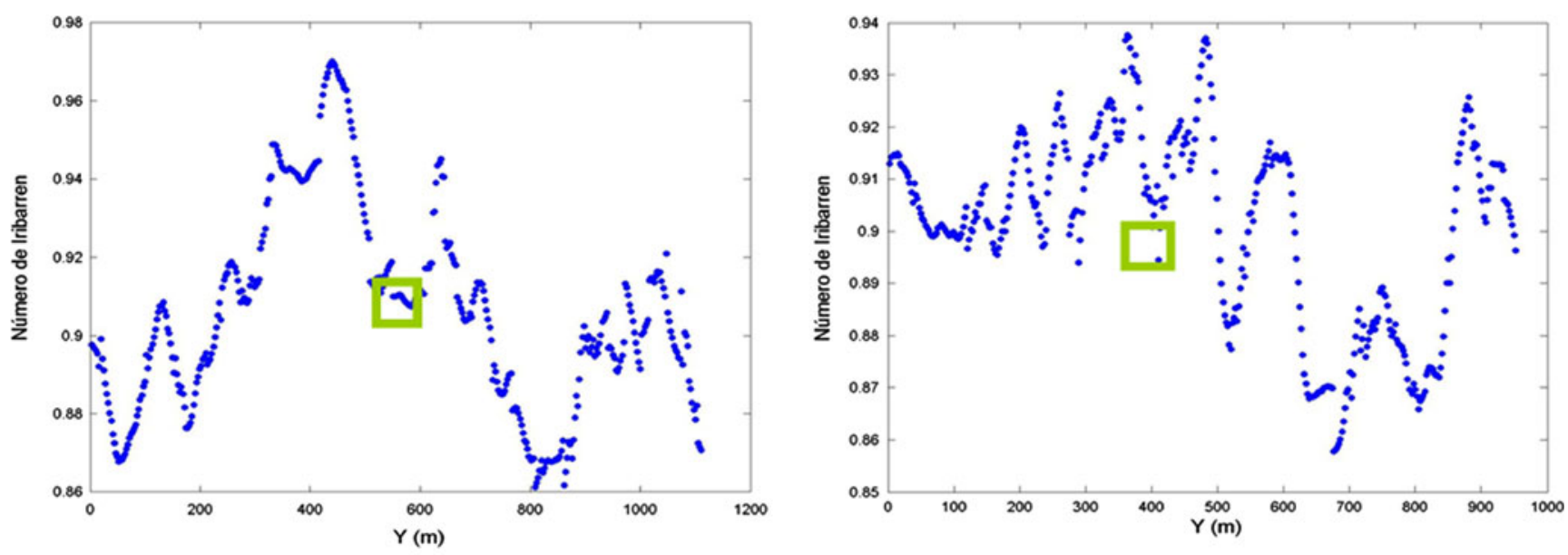

$\mathrm{C} 1-\mathrm{H}=4.0 \mathrm{~m}, \mathrm{~T}=15 \mathrm{~s}, 45^{\circ}$

$\mathrm{C} 2-\mathrm{H}=4.0 \mathrm{~m}, \mathrm{~T}=15 \mathrm{~s}, 66^{\circ}$
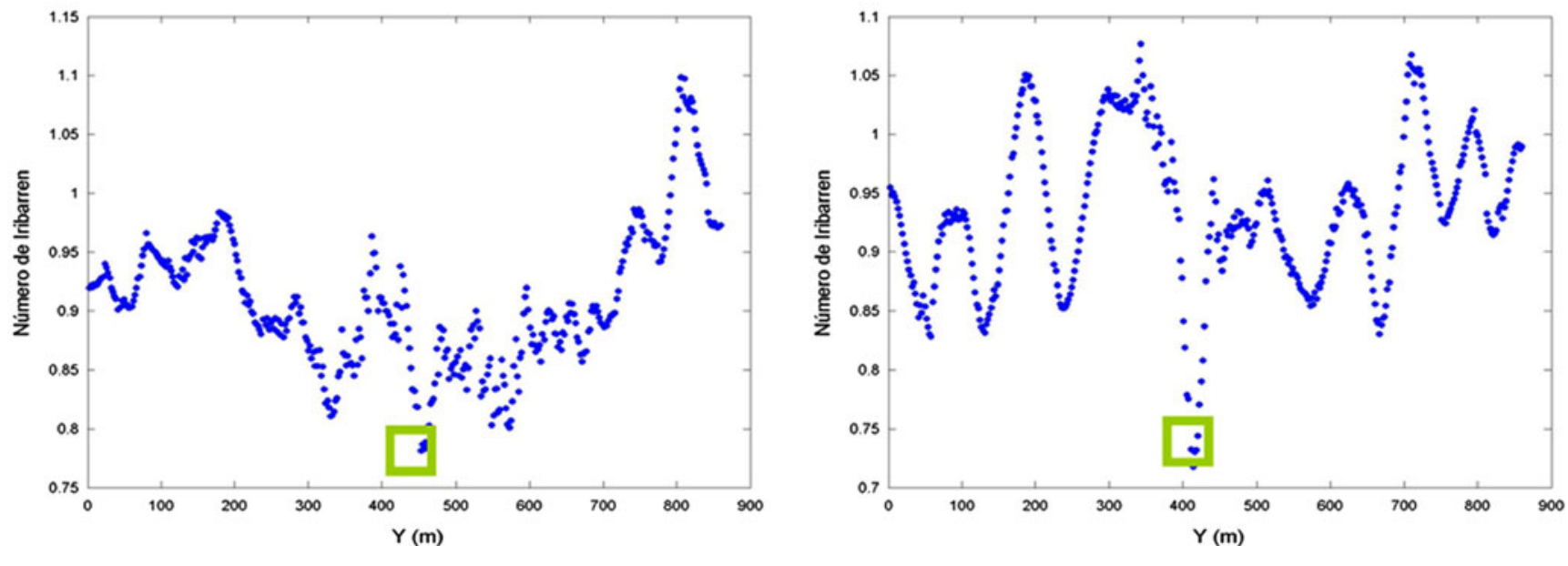

$$
\mathrm{C} 3-\mathrm{H}=1.5 \mathrm{~m}, \mathrm{~T}=9 \mathrm{~s}, 45^{\circ}
$$

$$
\mathrm{C} 4-\mathrm{H}=1.5 \mathrm{~m}, \mathrm{~T}=9 \mathrm{~s}, 66^{\circ}
$$

Fig. 7 Iribarren number along the wave breaking line. The green rectangle represents the apex of the structure 
$a_{1}, a_{2}, b_{1}, b_{2}$ can be found. These estimates are derived from the auto-and cross spectra of the time series as follows:

$a_{1}=\frac{C_{\eta u}}{\left[C_{\eta \eta}\left(C_{u u}+C_{v v}\right)\right]^{1 / 2}}$

$b_{1}=\frac{C_{\eta v}}{\left[C_{\eta \eta}\left(C_{u u}+C_{v v}\right)\right]^{1 / 2}}$

$a_{2}=\frac{\left(C_{u u}-C_{v v}\right)}{C_{u u}+C_{v v}}$

$b_{2}=\frac{\left(C_{u v}\right)}{C_{u u}+C_{v v}}$

where $C$ denotes de co-spectrum, $\eta$ represents the free surface elevation and $u$ and $v$ the velocity components. The mean wave direction $\theta(f)$ and the directional spread $s$ (f) can be computed from:

$\theta(f)=\arctan \left(\frac{a_{1}}{b_{1}}\right)$

and

$s(f)=\left\{2\left[1-\left(a_{1}^{2}+b_{1}^{2}\right)\right]\right\}$

The estimated mean wave direction, $\theta(f)$, is accurate. However, the estimation of the directional spread of the sea must be crude when based on only a limited number of Fourier coefficients.

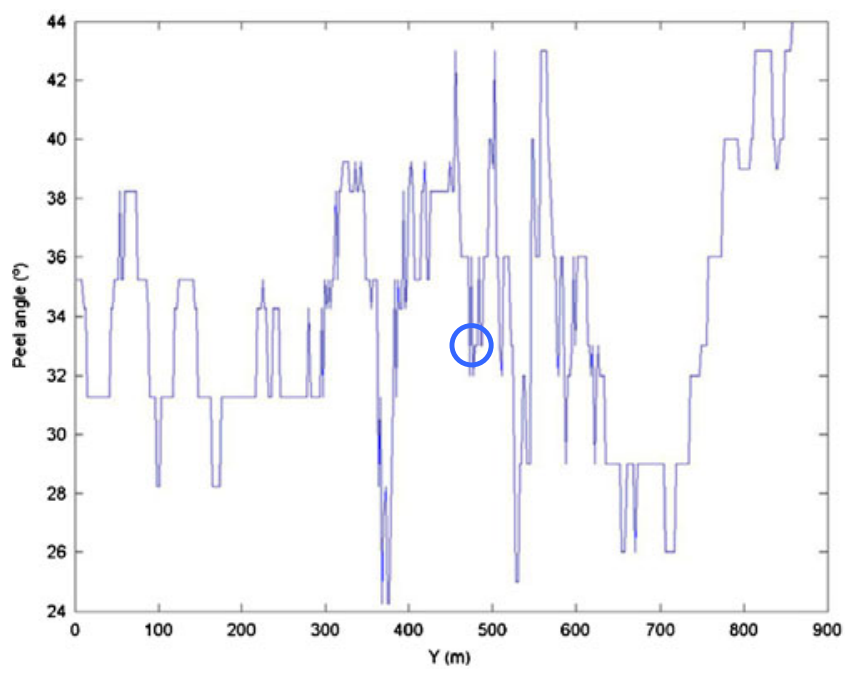

$\mathrm{C} 3-\mathrm{H}=1.5 \mathrm{~s}, \mathrm{~T}=9 \mathrm{~s}, 45^{\circ}$
For this study, an algorithm was developed in MatLab that organizes the information related to $\eta, u$ and $v$ for several points of the computational grid, and a direction is obtained through the DIWASP software developed at Met Ocean Solutions LTD (Johnson 2000). Based on that, the peel angle was determined and presented in Fig. 8 .

For the cases representative of common conditions, C3 and $\mathrm{C} 4$, the peel angle values indicate that the geometry of the case $\mathrm{C} 4$ would be more adequate for standard surfers, whilst the geometry of the case $\mathrm{C} 3$ would be more suitable for advanced/professional surfers.

\section{Coastal protection—currents}

To give a first indication related with coastal protection, the mean currents around the reef are analyzed. The output of the model corresponds to the velocity values at a depth $0.531 h$ under the water surface, where $h$ is the depth. The velocity at this depth is, by several authors, as Nwogu (1993), taken as the depth representative of the flow and was adopted by the authors of the COULWAVE model. In this work, as it is just a preliminary analysis of the flow giving an indication on the sediment transport, the output velocity at a depth $0.531 \mathrm{~h}$ under the water surface is used to determine the velocity cells near the shoreline (Fig. 9), that could give an indication of the sediment transport. Divergent cells indicate erosion near by the shoreline and convergent cells indicate sedimentation.

As can be seen in the figure, for all the cases, convergent cells appear, indicating a possible sedimentation near the shoreline, suggesting that the chosen geometries are advantageous for both coastal protection and improving surf

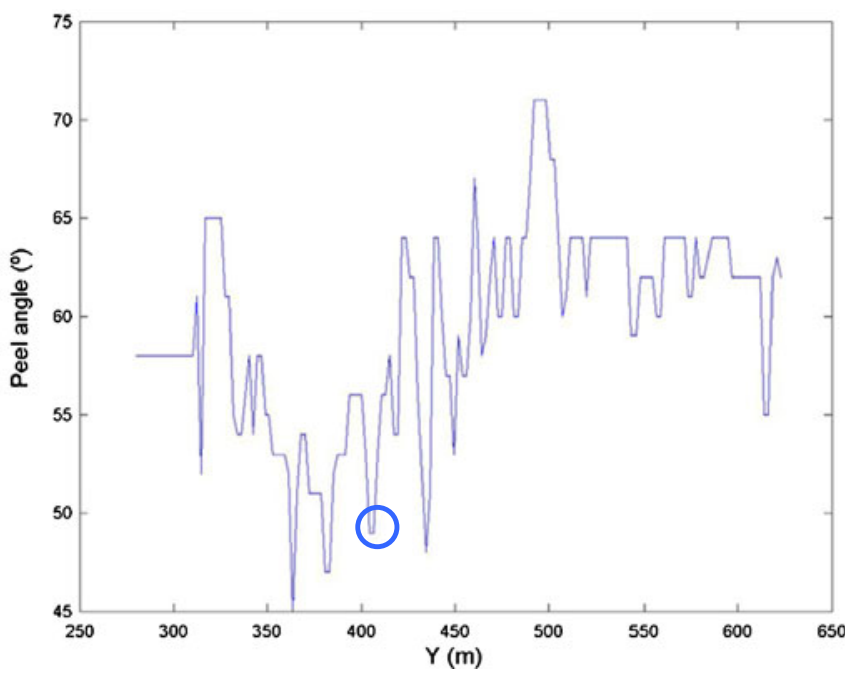

$\mathrm{C} 4-\mathrm{H}=1.5 \mathrm{~m}, \mathrm{~T}=9 \mathrm{~s}, 66^{\circ}$

Fig. 8 Peel angle along the breaker line. The blue circle represents the apex of the structure 

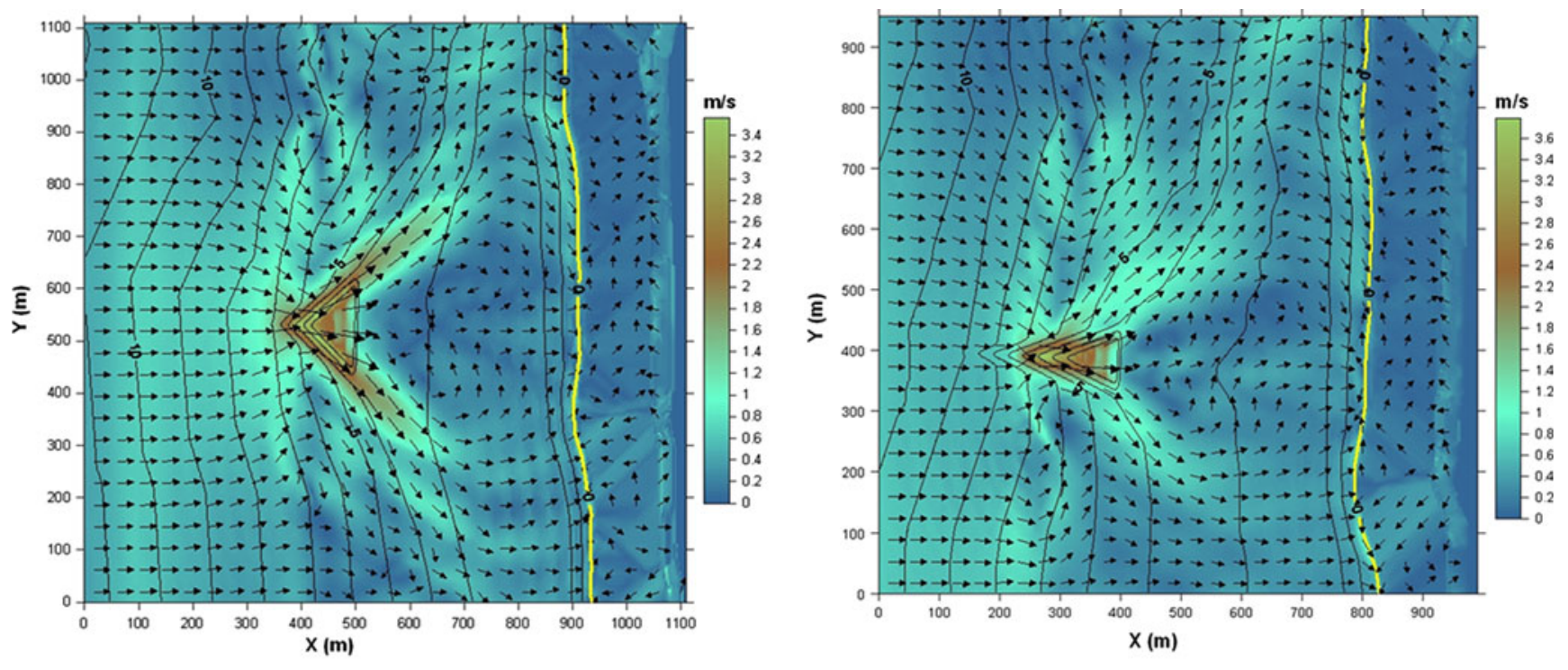

$\mathrm{C} 1-\mathrm{H}=4.0 \mathrm{~m}, \mathrm{~T}=15 \mathrm{~s}, 45^{\circ}$

$\mathrm{C} 2-\mathrm{H}=4.0 \mathrm{~m}, \mathrm{~T}=15 \mathrm{~s}, 66^{\circ}$

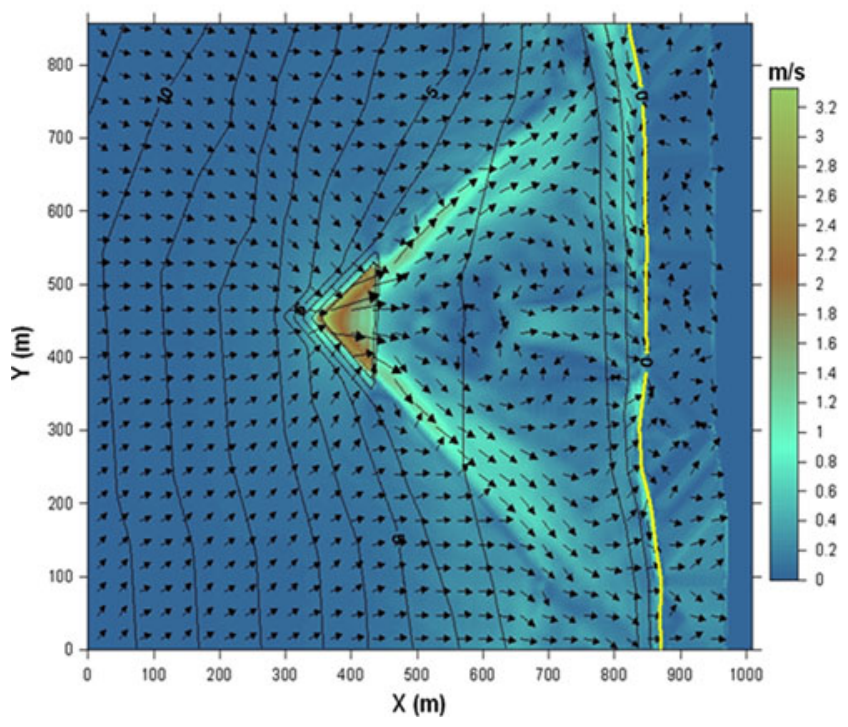

$\mathrm{C} 3-\mathrm{H}=1.5 \mathrm{~m}, \mathrm{~T}=9 \mathrm{~s}, 45^{\circ}$

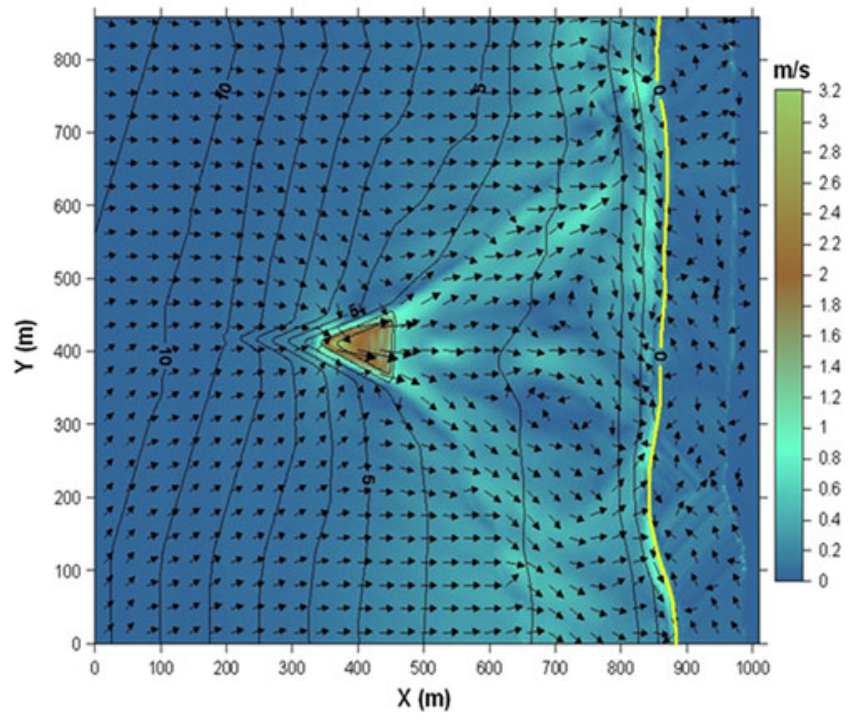

$\mathrm{C} 4-\mathrm{H}=1.5 \mathrm{~m}, \mathrm{~T}=9 \mathrm{~s}, 66^{\circ}$

Fig. 9 Velocity patterns of cases $\mathrm{C} 1$ to $\mathrm{C} 4$

conditions. As referred before, a morphological study should be done in order to confirm these results.

\section{Conclusions and future developments}

The Leirosa sand dune system, located to the south of Figueira da Foz, is characterized by strong erosion, mainly due to littoral drift retention caused by the Figueira da Foz port and the reduced sediment deposition which is a consequence of the interventions carried out in the Mondego River (Duarte and Reis 1992). In consequence, several dune rehabilitation interventions have been performed.
This study aims to analyse a MFAR functionality as an innovative and alternative way of protecting the coastline and its contribution to the improvement of local surfing conditions in Leirosa beach.

The reef's geometry and location were based on the theoretical study developed in Ten Voorde et al. (2008).

The efficiency and performance of the proposed geometry was analysed, in terms of surfability and coastal protection. The Boussinesq-type COULWAVE model was applied to study the wave propagation over the MFAR.

The simulated cases correspond to a storm condition and a local common condition for two reef geometries differing in the reef angle. 
The main surfing parameters analyzed are the breaker type, the peel angle, the wave height at breaking and the currents. The coastal protection assessment is estimated through the mean current field that gives an indication about the sediment transport.

With respect to surfability, both geometries suggest long breaker lines that are adequate for surf, with wave heights of around $2.5 \mathrm{~m}$ at the apex of the structure, for an incident wave of $1.5 \mathrm{~m}$. The analysis of the Iribarren number, for all the cases, indicates a plunging breaking, with values between 0.7 and 1.15 . The peel angle values indicate that the geometry with a reef angle of $66^{\circ}$ would be more adequate for standard surfers, while the geometry with a reef angle of $45^{\circ}$ would be more suitable for advanced/professional surfers.

Concerning coastal protection, the mean currents around the reef were used together with observations of the velocity cells near the shoreline to obtain preliminary indications on the sediment transport. For all the cases convergent cells seem to indicate a possible sedimentation near the shoreline. Nevertheless, a morphodynamic study needs to be executed to enable a deeper insight on the modes of erosion and sedimentation in the area.

Future studies should include an economical assessment regarding different types of materials and construction techniques for the MFAR.

Acknowledgments This project has been supported by the Fundação para a Ciência e a Tecnologia through grant PTDC/ECM/66516/2006 and PTDC/ECM/67411/2006.

\section{References}

Antunes Do Carmo JS, Schreck Reis C, Freitas H (2010) Working with nature by protecting san dunes: lessons learned. J Coast Res. doi:10.2112/JCOASTRES-D-10-00022.1 (in press)

Battjes JA (1974) Surf similarity. Proc. 14th International Conference on Coastal Engineering, pp 466-479

Bowen AJ (1969) Rip currents: 1. Theoretical investigations. J Geophys Res 74:5467

Dias JA, Ferreira O, Pereira AR (1994) Estudo sintético de diagnóstico da geomorfologia e da dinâmica sedimentar dos troços costeiros entre Espinho e Nazaré. Instituto de Conservação da Natureza [in Portuguese]

Duarte DN, Reis RP (1992) Estudo preliminar da evolução da linha de costa adjacente à embocadura do estuário do Mondego entre 1801 e 1989. Estimações das taxas de acreção e erosão costeiras. In: III Congr. Geol. España e VIII Congr. Latimoamericano de Geologia,
Salamanca, Spain: Universidad de Salamanca. 2: 146-150 [in Portuguese]

Fortes CJ, Capitão R, Neves MG, Monteiro PP, Mendes LS (2007) Viabilidade da implementação de um recife artificial para a prática de surf na praia de S. Pedro do Estoril e criação de uma estrutura de protecção e amarração do submarino Barracuda. Estudos de modelação numérica e física. Regimes de agitação marítima. Relatório 172/07. Abril

Henriquez M (2004) Artificial surf reefs. M.Sc. thesis. Delft University of Technology (www.waterbouw.tudelft.nl)

Jackson LA, Reichelt RE, Restall S, Corbett B, Tomlinson R, Mcgrath $\mathrm{J}$ (2004) Marine ecosystem enhancement on a geotextile coastal protection reef-Narrowneck reef case study. Proc. of the 29th International Conference on Coastal Engineering (Lisbon, Portugal), 3940-3952

Johnson D (2000) DIWASP, a directional wave spectra toolbox for MATLAB ${ }^{\circledR}$ : User Manual. Research Report WP-1601-DJ (V1.1), Centre for Water Research, University of Western Australia

Kennedy AB, Chen Q, Kirby JT, Dalrymple RA (2000) Boussinesq modeling of wave transformation, breaking, and runup. Part I: 1D. J Waterw Port Coast Ocean Eng 126(1):39-47

Longuet-Higgins MS, Cartwright DE, Smith ND (1963) Observation of the directional spectrum of SRA waves using the motions of a floating buoy. Ocean Wave Spectra, Prentice-Hall Inc.

Lynett P, Liu PL-F (2002) Modeling wave generation, evolution, and interaction with depth integrated, dispersive wave equations. COULWAVE Code Manual Cornell University Long and Intermediate Wave Modeling Package

Mendonça AC, Proença B, Fortes CJ, Neves MG (2009) Estudo da hidrodinâmica em torno do recife artificial para a prática do surf a construir em São Pedro do Estoril, Cascais. Aplicação dos modelos de Boussinesq: COULWAVE e FUNWAVE. Revista da Gestão Costeira Integrada

Mendonça AC, Fortes CJ, Capitao R, Neves MGT, Antunes Do Carmo J (2010) simulação da propagação de ondas sobre um recife artificial: Modelação numérica com o modelo de Boussinesq COULWAVE. 10th Congresso da Água, Alvor, Portugal

Neves MG, Fortes CJ, Mendes LS, Monteiro PP (2007) Viabilidade da implementação de um recife artificial para a prática de surf na praia de S. Pedro do Estoril e criação de uma estrutura de protecção e amarração do submarino Barracuda. Estudos de modelação numérica e física. Metodologias de trabalho. Relatório182/07-NPE

Nwogu O (1993) Alternative form of Boussinesq equations for nearshore wave propagation. J Waterw Port Coast Ocean Eng 119 (6):618-638

ten Voorde M, NEVES MG, Antunes Do Carmo JS (2008) Estudo Preliminar da Geometria de um Recife Artificial para Protecção Costeira e para a Prática de Surf na Costa Oeste Portuguesa. Rev Gest Costeira Integrada 8(1):65-79

Walker JR (1974) Recreational surf parameters. Tech. rept. 30. University of Hawaii, James K.K. Look Laboratory of Oceanographic Engineering

Wei G, Kirby JT, Sinha A (1999) Generation of waves in Boussinesq models using a source function method. Coast Eng 36:271-299 